\title{
A HATÁRMENTI FEKVÉS SZEREPE A FALUSI TELEPÜLÉSEK ÉLETÉBEN
}

\section{KOVÁCS TERÉZ}

A Magyar Tudományos Akadémia Regionális Kutatások Központjában 1986-ban átfogó kutatási program kezdổött a határmentiségrổl. A kutatásvezetổ a kutatás feladatát két alapkérdésben fogalmazta meg:

a.) a vizsgált terület állapotának létrejöttében valójában milyen szerepe volt és van a határmenti fekvésnek, illetve mennyiben befolyásolják azt más tényezók;

b.) milyen lehetôség van a szomszédos országokkal való együttmúködésre, az egyeztetett és reális terveken alapuló közös területfejlesztésre (akár harmadik ország anyagi forrásainak igénybevételével is), illetve a kényszerũen egyoldalú területfejlesztésre (Erdôsi 1988, 23.).

A vizsgálat tárgyát képezô határmenti zóna kijelölését a Magyar Tudományos Akadémia Regionális Kutatások Központja kutatói csoportja végezte, s ez a Magyarország teljes területére kiterjedô határsáv 803 falusi (községi) és 27 városi települését ölelte fel.

A kutatás szociológiai részének vezetôjeként egy hat fổs csoporttal tíz országhatár menti falusi településben végeztem empirikus felmérést. A kutatás végén született következtetéseim így kizárólag a falusi településekre vonatkoznak. A felmérés két téma köré összpontosult. Az elsô, hogy a határmenti fekvésnek milyen elốnyei és hátrányai vannak a település lakóinak életére, és ennek eredményeként megadom a határmentiség szociológiai definícióját. A második a vizsgált települések társadalmi rétegzôdése. Jelen írásomban az elôbbi témakörrel kívánok foglalkozni.

Az elsố probléma, amit kutatásom során kénytelen voltam tudomásul venni, hogy a határmentiségnek a hazai szakirodalomban kevés kutatási elổzménye van, a szociológiában meg éppenséggel semmi. Maga a probléma pedig annyira összetett, hogy megoldásához elengedhetetlen az interdiszciplináris megközelítés.

\section{Kutatási elổmények}

Azt a kevés kutási eredményt, amely e témakörben létrejött, a földrajztudomány szolgáltatta. Itt egy kéziratra (Kocsis 1988) és néhány publikált tanulmányra hivatkozhatok (Tóth és Csatári 1983; Erdôsi 1988, 1989; Berényi 1988; Zala 1988). Az említett kutatási program keretén belül számos tanulmány született, e tanulmányok írói azonban csak annyiban kötôdtek a kutatáshoz, hogy különbözố témákat vizsgáltak a határ mentén.

Mivel tanulmányomban abból indultam ki, hogy a határmentiség problémájához csak interdiszciplinárisan lehet közelíteni, azt a megoldást választottam, hogy a földrajztudomány meglévố eredményeit újraértékeltem, és hozzákapcsoltam sajât szociológiai kutatásaim eredményeit. 
Tettem ezt abban a reményben, hogy kezdeményezésem esetleg vitát vált ki, melynek során a határmentiség-probléma megoldása terén elốbbre jutunk.

Leggyakrabban maguk a geográfusok is a falusi településeket vizsgálták a határ mentén, ami számomra jó kiindulópontként szolgált. A határmentiségrôl szóló megállapításaikat, és ezzel kapcsolatos észrevételeimet három pontba foglalom.

A. A geográfusok leggyakrabban a népességszám alakulását vizsgálták. Egyszerú volt a helyzet, amikor a határmenti fekvésnek a lakosságszám alakulására gyakorolt pozitív hatását kutatták. Számszerứleg mutatták ki, hogy az államhatár megjelenésével a határátkelởhellyé váló települések népességszáma emelkedett. Véleményem szerint következô feladatuk ebben az irányban annak megvizsgálása lenne, hogy a határ meghúzásával megszüntetett vasút, elsôés másodrendũ országút milyen hátrányokat jelentett a határmenti települések lakóinak életkörülményeiben. Amikor a lakosságszám csökkenésének okát vizsgálták a határ mentén, akkor a geográfusok megmaradtak saját szaktudományuk korlátai között. Magát a témát - a lakosságszám csökkenését - a legkülönbözổbb népességföldrajzi szemléltetố eszközök figyelembevételével és alaposan kutatták. Még az sem kifogásolható, hogy a lakosságszám csökkenést okozati összefüggésbe hozták az elmaradottsággal. Vitatom viszont azt, ahogyan összefüggést állapítottak meg az elmaradottság és az országhatár menti fekvés között. ${ }^{1}$ Pontosabban: nem állításukat vitatom, hanem hiányolom ezen állításuk bizonyítását. Itt föl kellett volna tárniuk a határmentiségnek azokat a sajátos jellemzỏit, amelyek kizárólag a határ mentén érvényesülnek. A lakosságszám csökkenés nem tekinthetố sajátos jellemzōnek, mert az ország belsejében lévố elmaradott falvakra is érvényes.

B. A geográfusok a határmenti térségeket perifériának nevezik. Az országhatár valóban periféria a szó földrajzi értelmében, mert ott a nemzetgazdálkodás és a közigazgatás lehatárolódik, ám azok a szerzổk, akik a népességszám csökkenést vizsgálták a határ mentén, a perifériát negatív minôsítésként, az elmaradottság szinonímájaként használták.

Nem tartom elfogadhatónak, hogy a határ mentét, a geográfusokhoz hasonlóan, perifériának (az ország fổvárosát és még esetleg az ún. ipari tengelyt centrumnak) tekintsem. A centrumperiféria fogalompárt szerencsésebbnek tartom Immanuel Wallerstein értelmezésével összhangban használni. Szerinte a 16. században kialakult a modern világrendszer, amelynek voltak központi zónái (Anglia, Németalföld és közvetlen szomszédságuk), félperiférikus zónái (ide elsősorban a Földközi-tenger melléki országok tartoztak) és a periféria, ahová Magyarország is tartozott.

Ez a három zóna olyan társadalmi rendszert jelentett, amely gazdasági téren összekapcsolódott, de egyébként a kultúrák és politikai rendszerek sokaságát, autonómiáját is feltételezte. ,, A világrendszer létét pedig azok az egymással harcban álló erốk alakítják, amelyek e világrendszert éppen a benne ható feszültségek révén tartják egységben és azáltal szakítják szét, hogy minden egyes csoport örökké a világrendszer saját elổnyeire történố átalakításának módjait kutatja."'2 (Wallerstein 1983). A centrum és a periféria között tehát munkamegosztás volt, amely nem úgy múködött, hogy a centrum a megtermelt többletjövedelembốl részarányához képest tartósan nagyobb mértékben részesült (mert akkor az felbomlott volna); a cserearányok hosszú idốn keresztül éppen a perifériának kedveztek. A perifériát és a centrumot a másság jellemezte, és ez elsốsorban a munkatípusok (a munkakultúrák) tekintetében érvényesült. ,„A periférián, illetve a külsô erổtérben való tevékenység más-más gyakorlatot kívánt meg. Valamely gazdasá- 
gilag erổsebb csoport csak a periférián volt képes pozíciójának megôrzésére"3 (Wallerstein 1983).

E világrendszeren kívül léteztek birodalmak, ide Wallerstein Oroszországot és az Ottomán Birodalmat sorolta. A világrendszer és a birodalom között társadalmi vákuum keletkezett, a birodalom más elveken múködött, mint a világrendszer. A birodalomban egységes politikai rendszer volt, amely önellátó gazdaságot épített $\mathrm{ki}, \mathrm{s}$ az egészében ellenôrizte és elszigetelte önmagát a világrendszertốl. A modern világrendszer - Wallerstein szerint - immár ötszáz év óta áll fenn mint világgazdaság, anélkül, hogy világbirodalommá alakult volna, és pontosan e különlegességében rejlik erejének titka. A világrendszer határai - teszi még hozzá - mindig alakulófélben, cseppfolyós állapotban vannak, tehát változnak.

Annak ellenére, hogy Magyarországon gyakran idézik Wallersteint, mégis ilyen hosszan ismertetem elméletét, és ennek kettổs oka van. Egyrészt nézetét össze kívánom hasonlítani az idézett geográfusok nézeteivel. Ami ôket illeti, vagy nem definiálják a centrum-periféria fogalmakat, vagy olyan szerzôkre hivatkoznak, akik (pl. Berend T. Iván és Ránki György) szintén Wallerstein elméletére támaszkodnak. Másrészt szeretném hangsúlyozni, hogy Wallerstein megközelítése mind a világrendszert, mind a perifériát illetôen nemcsak gazdasági, hanem egyúttal politikai is. Az eddig említett szerzôk a centrum-periféria fogalompárt pedig csak gazdasági értelemben használták. Továbbá: Wallerstein Magyarország 16. századbeli helyzetét jellemezte perifériaként, a témával foglalkozó geográfusok pedig azt a mostani helyzetre és az országon belüli régiókra vonatkoztatták. Magyarország 1947 utáni világgazdasági helyzetével Wallerstein nem foglalkozik, de ha pontosan követjük az ố elméletét, akkor errôl a korról mint egyfajta ,,modern birodalmiságról” beszélhetünk.

A ,,modern" szót csak azért használom, hogy idốben megkülönböztessem a Wallerstein által elemzett kort a huszadik század második felétól. A szovjet típusú szocializmus effajta ,,modern birodalmiság" volt, mert egy központból irányítva figyelmen kívül hagyták e rendszerhez tartozó országok nemzeti sajátosságait. Így a ,,modern birodalmiság” jegyei nagyon hasonlítanak arra, amit a szerzổ a 16. századbeli Oroszországról és Ottomán Birodalomról írt, ismérvei pedig: az egységes politikai rendszer, az egyközpontból való irányítás és elszigetelổdés a világrendszertôl. A világrendszer most nem volt más mint Nyugat-Európa. Tehát nem az országhatár menti térségek váltak perifériává, hanem az egész ország került át a periféria-térségból a birodalmi térségbe. Mivel a birodalmi jegyek felfedezhetók mind a gazdasági, mind a politikai életben, hipotézisem szerint nem lehet lényeges különbséget találni a határmenti fekvésú elmaradott települések és az ország belsejében fekvố elmaradott települesek között.

C. Az említett geográfusok szemléletben még egy közös vonás fedezhetổ fel. Ez pedig az államilag szervezett gazdasági integráció és a kormányok közötti együttmüködés lehetôségeinek túlzott keresése. Integrációt terveznek oda is, ahol erre nincsenek meg a feltételek, illetve lehet, hogy megvannak ugyan, de arról nincs tudomásunk. Természetesen figyelembe kell venni azt, hogy amikor ốk kutattak, sốt amikor e szociológiai kutatás is folyt, másfajta rendszerek múködtek, mint manapság. Most viszont a kelet-európai változások már egyértelmúvé tették, hogy nem a magasszintư kétoldalú együttmúkködések halmozására van szükség, hanem hogy a kormányok a saját határmenti térségeikben — az ország többi részéhez hasonlóan - teremtsék meg annak feltételét, hogy a spontán folyamatok, az egyéni kezdeményezések jobban érvényesüljenek, a települések önállósága nagyobb legyen. Hagyni kell az embereket, döntsék el ma- 
guk, milyen kapcsolatba akarnak lépni a határ túloldalán lévô emberekkel, társaságokkal, intézményekkel, esetleg milyen munkakapcsolatokat akarnak és tudnak e relációban kiépíteni. A fejlett piacgazdaságban az integrációra majd csupán azért lesz szükség, hogy az egyéni kezdeményezéseket értelmes mederbe tereljék, felerôsítsék a kívánatos integrációkat és kiszűrjék azokat, amelyek társadalmilag nemkivánatosak. Én nem az integrációban, hanem a kapcsolattartás létében vagy nem-létében vélem a határmentiség problémáját felfedezni. A két megközelítés között az a különbség, hogy az integrációk feltételezik a két- vagy többirányultságot, és ehhez egyeztetni kell a feltételek sorozatát. Így létrehozásuk és megszakításuk egyaránt nehézkes, hosszadalmas és elbürokratizálódhat. (Gondoljunk csak arra, hogy az elmúlt 40 évben milyen kevés jelentôs államközi együttmû́ködés jött létre a határmenti térségekben, és ezek közül a legnagyobb, a gabcsikovo-nagymarosi vízlépcsố felépítése is kudarcba fulladt, sok nehézséget okozva mindkét félnek.)

Ezzel szemben nem szükséges, hogy a kapcsolat kétirányú legyen, és nem kell feltétlenül megállapodáson alapulnia. A szükségletektől függốen könnyen létrejöhet, változhat, megszűnhet. A kapcsolatban a hangsúly a kötôdésen van.

Ám a ,,modern birodalmi" rendszerben a falvak egymás között csak kivételes esetekben alakítanak ki különféle szerves kapcsolatokat. A határ mentén sem alakulnak ki sajátos , határmenti" kapcsolatok, melyek a szükségletek kielégítését tennék lehetơvé. A szociológia feladata pedig e kapcsolatok kutatása lenne.

\section{A határmentiség jelentôsége}

Vizsgálatunk során azt tapasztaltuk, hogy a határmentiség szerepe a falusi települések lakóinak életében a jelenlegi országhatár kialakulását követô, történelmileg rövidnek mondható 70 év alatt többször változott, s ez azért volt így, mert Magyarország világgazdasági helyzete is változott.

Az elsố korszak 1920-tól 1947-ig tartott. Ebből ki kell vonni az 1939 és 1945 közötti idôszakot. Magyarország ekkor a wallersteini értelemben vett perifériához tartozott. Vizsgálatunk során azt tapasztaltuk, hogy ebben a korban léteztek a legerôsebb határmenti kapcsolatok. Élt a kettôs birtoklás intézménye, és a földtulajdonosok átjárhattak a másik országba ottmaradt földjeiket megművelni. Ezek az átjárások - a román határ kivételével, ahol ez engedélyhez volt kötve - teljesen szabadok voltak.

A határ meghúzásával a falvak sok esetben elveszítették korábbi vonzásközpontjukat. Új központokat jelöltek ki, de az átrendezốdés a falusi lakosságra lehangolóan hatott, mert ezek az új központok kisebb városok voltak, és távolabbra estek tôlük. Pl. a vállajiak Nagykároly helyett Mátészalkára, a biharugraiak Nagyvárad helyett Berettyóújfalura, az öttömösiek Szabadka helyett Kiskundorozsmára, Kiskunhalasra és részben Szegedre, a hídvégardóiak Kassa helyett Edelénybe jártak. Ezek az átrendezódések csak olyan helyen történtek meg, ahol magyarlakta területeket választott szét a határ, mert pl. a drávaszabolcsiak továbbra is zavartalanul jártak a határ túloldalán lévố, horvátok lakta donyimihajloveci piacokra. Ez utóbbi vonatkozik az osztrák határra is, ahol nemcsak a szokásos heti piacokra jártak ,ide-oda" az emberek, hanem a magyarok oda mentek napszámba, mert ott többet fizettek. Az osztrák kốművesek pedig átjár- 
tak a magyarokhoz házakat építeni, mert ôk voltak az elismert mesterek. A határmenti magyar napszámosok túloldalt egy fejlettebb munka- és eszközkultúrával találkoztak (pl. mezôgazdasági kisgépekkel, öngyújtóval), és azt áthozták Magyarországra is. A burgenlandi magyar diákok Sopronban és Kôszegen jártak középiskolába.

A kettéválasztott homogén magyarlakta vidékek között azért nem lehetett a határ meghúzása elổtt kialakult kapcsolatokat fenntartani, mert a szomszédos országok jobban féltek a területi visszacsatolástól, mint ott, ahol a meghúzott határok egybeestek az etnikai határokkal.

A csempészés azonban korlátlanul folyt minden egyes határ mentén. Az emberek nemcsak a hiánycikknek számító, és nélkülözhetetlen sót szerezték be a határ túloldalán, de a csehszlovák és jugoszláv határon még a lovakat is átsétáltatták. Ebben a korban tehát végül is egy nagyon laza, gyengén ellenôrzött határról van szó, ahol a korábbi kapcsolatok kisebb-nagyobb része fennmaradt. Éppen ezért az idổs generáció körében erre az idôszakra jó emlékekkel gondolnak vissza. A közép és fiatal generációnak e korról nincsenek személyes emlékei.

1939 után nagy lakosságvándorlás indult el Erdély irányába. Ez a vándorló tömeg arányaiban nagyobb részben került ki a határ széléról, mint az ország belsejébốl, de akik beljebbról jöttek, azok is megálltak kis ideig a határ szélén ismerősöknél, rokonoknál. 1945 után a határ visszaállításával ez a folyamat ellenkezõ irányban megismétlő̉dött, sỗt ugyanez fokozottan érvényesült a csehszlovák-magyar határon, ahol a közismert kitelepítés zajlott. Ezek az események megrázkódtatták a helyi lakosságot. A szemtanúk körében még mindig él az a tudat, hogy a határ ideiglenes valami, aminek változásához nekik nincsen semmi közük, ám következményeihez annál inkább. Ennek tudatában élni bizonytalanságot és kiszolgáltatottságot jelent.

1947-tól kezdôdik egy új szakasz, amely nagy belsô eltérésekkel, de egészen 1989-ig tart. Ekkor Magyarország világgazdasági helyzete az említett ,,modern birodalmisággal” jellemezhetỗ. Kétségtelen, e korszakon belül óriási különbségek vannak, így akár több szakaszt is kijelölhetnénk, de a nemzeti sajátosságok figyelmen kívül hagyása, és az ezt fenntartó monolitikus rendszer mindvégig fennáll; a határmenti mozgáslehetôségek, s ezáltal a kapcsolattartás is végig az elóbbi kor szintje alatt maradt. 1947-ben megszủnt a kettôs birtoklás, az emberek ettól kezdve csak a szigorúan kijelölt határátkelóhelyeken, olykor óriási kerülớvel járhattak át a területileg néha nagyon közel esố, és végeredményben szomszédos településekre. Míg eddig a határmentiség csupán szociálpolitikai kérdésként fogható fel, e kortól kezdve már politikai és fejlesztéspolitikai döntések következményeként jelent meg.

A szomszédos országokkal kialakult politikai, illetve szövetségi kapcsolatoknak megfelelôen változott a határ erôssége. Az ötvenes években a , ,legerôsebb" a jugoszláv és az osztrák határszakasz lett. E határokat aknákkal, az osztrákot még szögesdróttal is védték, és mindkettốt határsávval erổsítették. A határsávot egy belsổ megerősített , ,határ" választotta el az ország belsejétôl, ahová ki-belépni csak igazoltan lehetett. A hortobágyi munkatáborok elítéltjeit nagyrészt a jugoszláv és osztrák határ mentéról szedték össze. A Gulyás testvérek Törvénysértés nélkül címü filmje drámai módon tárja fel, mit fizettek az emberek azért, hogy a határ mentén laktak. Kutatásaink során arról is megbizonyosodtunk, hogy a Hortobágyra hurcolt családokat nem engedték vissza volt lakóhelyükre.

Ezek a feszültségek kihatással voltak a fejlesztéspolitikára, a beruházások támogatására. Igaz, ez fốleg a határmenti városi településeket érintette, de a falvakban is megnyilvánult a magánépítkezési engedély korlátozásán keresztül. 
A jugoszláv határ elôbb, az osztrák késốbb , ,lazult fel”. A hetvenes, de különösen az 1980-as években ,,legkeményebbé” már a szovjet-magyar és a román-magyar határ lett. Ezeknek a határszakaszoknak az a sajátossága, hogy önmagukban, sổt minden kényszerítố eszköz hiányában, és az azonos szövetségi elkötelezettség ellenében is képesek voltak merevnek megmaradni.

A mai kelet-európai változások arra engednek következtetni, hogy ebben a régióban a határok fellazulnak, és egy sokoldalú kapcsolat kialakítása elốtt állunk, amely idôvel remélhetôleg oda vezet, hogy a határok csupán vonalak lesznek a térképen.

Az általam ,,modern birodalmiságnak" nevezett korszakban nem voltak meg a kapcsolatteremtés feltételei. Ami mégis kialakult, az spontán, központi szervek irányítása nélkül, sổt gyakran azok szándéka ellenében jött létre. A szabály az, hogy nincs kapcsolat, s ami van, az kivétel. Az alábbiakban ilyen kivételekrốl szólok.

Bánátban az elszigetelt magyar falvak lakói az 1960-as években tömegesen hagyták el a falujukat, és költöztek Szabadkára. Az elvándorlás olyan méretũ volt, hogy egész utcák néptelenedtek el. Ez az elvándorlási hullám egybeesett az ország más részeire is jellemzõ iparosítási és urbanizációs folyamattal. Az elvándorlás sajátossága az, hogy mindannyian Szabadkára mentek, s ennek négy oka volt. Elôszzör is azért mentek oda, mert gyerekeik számára csak ott látták biztosítva az anyanyelvi oktatást; másodszor, nem vagy rosszul beszélték a szerb-horvát nyelvet, ez kisebbrendûségi érzést váltott ki bennük, s úgy érezték, hogy ezt a ,, hibájukat" Szabadkán fogják legjobban tolerálni. Harmadszor azért mentek Szabadkára, mert vágytak arra, hogy nézhessék a magyar televízió adásait, és erre ott volt mód. Negyedszer, kötôdtek Magyarországhoz, és elổnyt láttak abban, ha a határmentére költöznek, mert így gyakoribb és sokrétúbb kapcsolatot tudnak teremteni az anyaországgal.

A nemzeti kisebbségeket a határ szinte magához húzta, sajátos térfolyamatokat indított el e közösségekben. Azzal, hogy térbelileg közel kerültek a határhoz, mely ráadásul ez idóben már nagyon nyitott volt, óriási elổnyük keletkezett a nemzeti kultúra ápolása és a nemzeti fennmaradás terén. Azok a falusi magyarok, akik szerblakta városokba költöznek, többségükben egy-két generáció múlva elveszítik anyanyelvüket és asszimilálódnak. E példa ugyan a határ túloldaláról való, de általános érvényưnek tekinthetổ a határmenti helyzet és a nemzeti kisebbségi lét összefüggésében.

Másik eset: Drávasztárán 47 diák miatt tartanak fenn egy nyolcosztályos iskolát. A falu lakossága horvát nemzetiségứ, és a helyi iskolában a tanitás részben e nyelven folyik. Ha nem lenne ott természetes határként a Dráva, a felsổtagozatos diákokat nyugodtan lehetne naponta utaztatni a legközelebbi, túloldalon lévổ horvát iskolába. Ott a diákok jobban és helyesebben sajátítanák el a nyelvet, megismernék a saját nemzeti kultúrájukat. Drávasztárán pedig elég lenne az alsótagozatot fenntartani, s ezzel mindenki nyerne. Eddig egy határ mentén sem kerülhetett sor hasonló megoldásokra. A mostani kelet-európai változások eredményeként talán már a közeljövốben lehetôség lesz arra, hogy egy határmenti nemzetiségi település iskolaszéke vagy valamilyen szülói küldöttség felkeresse a szomszédos ország hozzájuk legközelebb esổ településének iskolaigazgatóját, és közvetlenül megkérdezhesse, iskolájukban tudják-e fogadni az ô gyerekeiket is.

Ha az egyéni, ezen belül is a kisvállalkozások beindulnak, és ha a termelốk közvetlenül kereskedhetnek a szomszédos országban is, akkor elképzelhetô, hogy egyes határmenti települések 
vonzóvá válnak. Néhol bizonyos elônyöket és sajátos lehetôségeket kínálhat a határmente, s az egyes társadalmi csoportok számára vonzó lehet.

A kapcsolatok eddig is elsôsorban a nyelvi kötôdés, az információszerzés és nem a gazdaság területén alakultak ki. Kutatásaink eredményei azt igazolják, hogy a határ mentén élố emberek mindennapjaiban a szomszédos ország tv-müsorainak nézése helyenként fontos szerepet játszhat. Ha a szomszédos ország tv-mûssorai anyanyelvén szólnak, ha jobb szórakozást, több információt nyújtanak, vagy más világszemléletrốl tanúskodnak, mint a saját országuk tv-adásai, akkor az felkelti az ott élốk érdeklôdését. Ebbốl kifolyólag az ország különböző határszakaszán a szomszédos ország tv-músorainak nézettsége is más-más módon alakul. Az osztrák határ mentén három megkérdezett közül kettô nézi az osztrák tv-müsorokat. A jugoszláv határnál a ,Vajdaság felett” minden második, Horvátországnál minden harmadik megkérdezett nézi a szomszédos ország adóit. A csehszlovák határról már csak minden hetedik, a román határnál pedig minden kilencedik megkérdezett sorolható ebbe a kategóriába.

A felmérésbe bekerült egy osztrák határmenti, horvát nemzetiségũ falu is (Szentpéterfa). Ott az osztrák mellett minden második megkérdezett a zágrábi tv adásait nézi. Tipikusnak tekinthetô az egyik idổs ember válasza: ,,Én minden nap egyszer meghallgatom a magyar, az osztrák és a jugoszláv híreket is, így tudom, mi történik a világban."'

Tudjuk, hogy a csehszlovák és a román forradalmat megelốzõ idôszakban milyen fontos szerepe volt a magyar TV Panoráma címũ adásának a túloldali határmenti lakosság információszerzésében. Az érintettek nyilatkozatából az is kiderült, hogy az így szerzett információkat továbbították az ország belsejében lakó ismerôseiknek, barátaiknak. Ez azonban csak a mai idốkre érvényes, a jövốben az átjátszóadók kiépítésével és a múholdsugárzó TV-müsorok széles körének beindításával a Magyar TV adásainak mưssorait az egész Pannon-medencében lehet majd nézni.

\section{Határmentiség és elmaradottság}

Milyen szerepe van a határmenti fekvésnek az ott lakók mai életében? - ez kutatásunk alapkérdése. Már írásom elsố részében kifejtettem, hogy véleményem szerint a falusi települések elmaradottságában a határmenti fekvés nem lényeges tényezô. Másod-illetve harmadrendũ szerepe lehet a nagyon elmaradott térségek esetében, de elsôdleges semmiképpen.

Az elốzô fejezetben már volt szó arról, hogy 1920 után a határmenti falvak fejlôdésében nem történt akkora törés, mint az azonos fekvésũ városi települések esetében az feltételezhetố. $\mathrm{Az}$ új központokhoz való átrendezổdés kisebb-nagyobb nehézségekkel, de megtörtént. 1947 után már rendkívül differenciált módon alakult az egyes határmenti falvak sorsa. Viszont csak 1960 után és ezt a népességföldrajzi vizsgálatok is alátámasztják - kezdett el a lakosság a határmenti falvak egy részében jelentósen csökkenni, ami szinte két évtizedig folyamatosan tartott. ${ }^{4} \mathrm{E}$ téren csak az 1980-as években állt be némi stabilizálódás, vagy éppen népesség-növekedés, amennyiben cigány lakosság költözött be tömegesen az érintett falvakba.

Szeretném azonban hangsúlyozni, hogy ez nem határmenti jelenség, hanem az ország minden elmaradott térségére érvényes, és összefüggésbe hozható azzal a társadalmi-gazdasági és településpolitikai folyamattal, amely az 1960-as évektól kezdôdôen jellemezte Magyarországot. 
1960-tól az a paradox helyzet állt elổ, hogy míg a politikai nyomás a határmenti falvakban lényegesen lecsökkent, és már csak az osztrák határ mentén volt jelentốsége, addig településpolitikai szempontból egy eddig ismeretlen folyamat indult el, amely igen kedvẹzôtlenül érintette az ún. elmaradott térségek falvait; és az országhatár jelentôs része (szinte az egész keleti, délnyugati és északkeleti rész) is ide tartozott. Ezt a folyamatot extenzív iparosításnak és modernizálódásnak hívjuk. A korábbi idôszakban, amikor Magyarország a világrendszer perifériájához tartozott, a falu és város között munkamegosztás létezett, amit Erdei Ferenc a Magyar város címú könyvében írt le. Amikor Magyarország a ,,modern birodalmiság” korába lépett, elkezdổött a falu város általi újszerû́ kizsákmányolása; egy rendkívül összetett folyamat, amelynek csak egyik látványos összetevôje a lakosságszám csökkenése.

A korszak az ún. második kollektivizálással kezdôdött, amikor a tsz-ek nem vagy nagyon rosszul tudtak fizetni. Aki tehette, más kereseti forrás után nézett. Késốbb a mezôgazdaság gépesítésével csökkent a föld eltartóképessége, ami újabb elvándorlást eredményezett.

Az 1970-es évtized a különbözô központosítások kora. Az iskolák, a tsz-központok, a tanácsok nagyobb településekre koncentrálódnak. Mindez magával vonta a lakosság azonos irányú elvándorlását. Az aprófal vakból a fiatalabb, a szakképzettebb és tehetôsebb csoportok költöztek el. Az elköltözés tehát szelektív volt. A szocializmus extenzív iparosítása a nagyobb településeknek kedvezett. (Ez alól csak a speciális funkcióval rendelkező aprófalvak képeztek kivételt.) Egy határmenti falu központi funkcióval pedig nemigen rendelkezhetett, mert a határ zárt és merev volt.

A modernizációs folyamat részeként megindult az infrastruktúra fejlesztése. Addig a falvakból minden szomszédos településre el lehetett jutni a nyárfás földutakon, lovas kocsival vagy gyalog. Ekkor viszont kiépült egy mứt, amely átszelte a falut. Határmenti falvak esetében zsákutakról, egyirányú utakról beszélhetünk.

Az 1960-as évektốl kezdổdổen egy modernizálódó társadalomról beszélhetünk, amely szerkezetében átrétegzốdik, de az életkörülményekben, különösen a felemás infrastrukturális fejlesztés eredményeként nagy ellentmondások keletkeznek, s ez elsôsorban a falusi településekre érvényes.

Az említett drávasztárai diákok iskoláztatása is könnyen megoldódhatna akkor, ha Drávasztáráról közvetlenül vezetne müút a szintén horvátlakta Felsôszentmártonba. A meglévố mûuútviszonyok közepette a két falu között csak hosszú kerülố úton, egy ,,u” alakú ív leírásával lehet közlekedni. Ilyen példával azonban találkozunk az ország belsejében is, csak esetleg nem olyan gyakorisággal, mint a határ mentén.

Terepmunkánk során arra a meggyőzốdésre jutottam, hogy a határ mentén lévố falvak mai lakói nem érzik úgy, hogy a határmenti fekvésben kell keresni az elmaradottság okát. Realisták, és mindennapi problémát jelent számukra a munkahelyek és a városok hiánya, illetve távolsága. A rossz infrastrukturális, közlekedési feltételek, a kedvezôtlen természeti adottságok és - ezt nem mondták ki maguktól, de hozzátehetjük - az egyéni vállalkozási hagyományok hiánya, és mindezen tényezốk összefonódása okozza a határmenti falvak sorsának kedvezôtlen alakulását.

A kutatás során hosszú ideig azzal az elốítélettel végeztem a terepmunkát, hogy az elmaradottság okait a határmenti fekvésben kell keresni. Tettem ezt azért, mert a meglévố szakirodalom és a közgondolkodás ezt sugallta. 
Véleményem szerint az a felfogás, miszerint a határmente elmaradott, érzelmi töltést hordoz, és a ,trianoni sokk" továbbélése. A Trianonból következổ mély sebek nemzeti kisebbrendüségi érzést szültek Magyarországon, amely 1920 után sovinizmusba csapott át.

1945 után nem történt meg ennek a nemzeti problémának az elfogadható rendezése, 1948 után pedig még a tudomány asztaláról is lesöpörték. A közgondolkodásban viszont tovább élt; a határ létéhez negatív képzetek kapcsolódtak az egész ország területén, ám a határ mentén ez kevésbé érvényesült, mint az ország belseje felé haladva. A határ mentén éló emberek reâlisabban látják kialakult helyzetük okait, ezért nyilatkoznak úgy, hogy nem a határ az oka az elmaradottságnak.

Úgy vélem tehát, hogy a ,trianoni sokk” és a ,,modern birodalmiság”, amely az ország egészére érvényes, az a két fogalom, amely útmutatóként szolgálhat a határmenti falusi térségek problémáinak kutatásakor.

\section{Következtetések}

Az eddigi határmenti kutatások során a témával foglalkozó szakemberek nem törekedtek arra, hogy különválasszák az ország egészére érvényes és az országhatár mentén jelentkezố sajátos településfolyamatokat, és hogy rámutassanak azokra, melyek mind két térségben egyaránt érvényesek. Úgy vélem, hogy túlértékelték a határmentiség szerepét a falusi települések elmaradottságában.

Ki kell emelni azt a sajátos tényt, hogy a magyar országhatár történelmileg rövid múltra tekint vissza, és megvonása zavart okozott a ki nem forrott nemzeti tudat fejlődésében. Az osztrák és a jugoszláv határ mentén élốk egy csoportja a ,,modern birodalom” korszakában komoly üldöztetésnek volt kitéve. Ezek feltárása és elemzése a történettudományra vár. Viszont nemcsak az érintett családok, hanem zömükben más jobb helyzetû́ társadalmi csoportok tagjai is elköltöztek a kedvezốbb adottságú településekre. Az elköltözések oka ezeken a területeken most már szociológiai módszerekkel nem kutatható. Akik ma a határ mentén élnek, és településük elmaradottnak számít, azok úgy vélik, hogy elmaradottságuk oka a munkahelyek hiánya, a város távolsága és a rossz közlekedés.

A határmenti térségek fejlesztési lehetổségét a közelmúlt pozitív kelet-európai politikai változásáig összekapcsolták a két szomszédos ország kormányai közötti tárgyalások sikerével. A kormányok közötti megállapodások és az integrációk is fontosak ugyan, de hatásuk elsôsorban az ország egészére érvényesül, s kevés közük van a határmenti településfejlesztéshez. A központban meghozott döntések nem érintik a határ mentén lakók életkörülményeit. A kishatárforgalmi megâllapodások meghozatalakor a döntés már lejjebb, a megyeközpontba került, de még mindig messze volt az érintettektốl, a helyi társadalomtól. Ezért az emberek nagyon kevés kapcsolatot tudtak teremteni a határokon túli területekkel. E kapcsolatok spontán, olykor legitim módon jöttek létre. Kialakításuk, fejlesztésük számtalan akadályba ütközött. Magyarország most a ,,modern birodalmiság” felszámolása felé halad. Ebben a folyamatban a kormánynak nem elsôsorban a szomszédos országok kormányaival kell tárgyalnia a határmentiség ügyében, hanem elôször minden országban meg kell teremteni annak a feltételét, hogy a szerves kapcsolatok kialakuljanak. Fel kell oldani azokat a korlátokat, amelyek az embereket akadályozzák 
abban, hogy a szomszédos ország polgáraihoz, intézményeihez és legkülönbözôbb közösségeihez (kulturálistól a munkaközösségekig) kötődjenek, és velük olyan kapcsolatot létesítsenek, amely megfelel érdekeiknek és igényeiknek. Ha ezek a folyamatok megindulnak, várható, hogy egyes határmenti települések lakói elốtt olyan lehetôségek nyílnak meg, amilyenek eddig nem voltak. E települések polgárai képesek lesznek majd több településfejlesztési problémát egyedül megoldani, falujuk sorsát is kezükbe venni. Hathatósabb településfejlesztési beavatkozásokra majd csak azokban a falvakban lesz szükség, amelyek most sem és egy szabadabb ország és országhatár esetében sem tudnak önerôbổl boldogulni.

\section{Jegyzetek}

${ }^{1}$ Ezekre az állításokra nagy hatással volt egy minisztertanácsi majd kormányhatározat, mely az elmaradott térségek fejlesztése érdekében született. Az elmaradott térségek körének meghatározását azonban nem tudományos igénnyel végezték; az Országos Tervhivatal Tervgazdasági Intézete néhány elốre meghatározott szempont alapján - köztük egyik volt az ország-, illetve megyehatár is - mechanikus elhatárolást végzett, amelyet a tervezési munka során alkalmazott.

${ }^{2}$ Wallerstein, I (1983) A modern világgazdasági rendszer kialakulása, Gondolat Kiadó, Budapest.

${ }^{3}$ Wallerstein, I. i.m.

4 Itt csupán a tömeges lakosságszám csökkenést szeretném hangsúlyozni. Természetesen nem szabad elfelejtkezni arról sem, hogy egyes falvakban (pl. az Ormánságban) a lakosság már a múlt század végén elkezdett fogyatkozni.

\section{Irodalom}

Almásy A. K.-Vaszilijevics, S. V. (1986) A határmenti kapcsolatok távlatai a mezógazdasági termelók termelési technológiájának adaptálásában, Gazdálkodás, XXX. 12.

Barcza G. (1986) Vas megye és Ausztria határterületek közỏtti munkamegosztásának és az együttmúködés agrárgazdasági lehetőségeinek kutatása, Gazdálkodás, XXX. 12.

Beluszky P. (1981) Két hátrányos helyzetư terület az Alföldön: a Közép-Tiszavidék és a Berettyó-Körös vidék, Alföldi Tanulmányok, V.

Beluszky P.-Sikos T. T. (1982) Magyarorszäg falutipusai, Budapest, MTA FKI.

Berend T. I.-Ránki Gy. (1979) Gazdasági elmaradottság, kiutak és kudarcok a XIX. századi Európában, Közgazdasági és Jogi Könyvkiadó, Budapest.

Boros Z. (1986) Határmenti települések kapcsolatai Vas megyében, Gazdálkodás, XXX. 12.

Berta J. (1988) Adalékok Biharugra helytörténetéhez (Kézirat).

Berta J. (1989) Biharugra (Kézirat).

Biesz K. (1988) Határmenti térségek demográfiai megközelítése (Kézirat).

Bögre Zs. (1989) Kilenc falu határmenti helyzetének elemzése (Kézirat).

Chadwich, F. A. (1988) Perceiving, analysing and coping with the local-global nexus, International Social Science Journal, August.

Csoba J. (1986) Nyirségi határmenti községek (Kézirat).

Csoba J. (1989) Településfejlódési folyamatok Vállaj és Nyírvasvári faluban 1960-tól napjainkig (Kézirat).

Enyedi Gy. (1980) Falvaink sorsa, Magvetô Kiadó, Budapest.

Enyedi Gy. (1988) A városfejlódés szakaszai, Akadémiai Kiadó, Budapest.

Erdósi F. (1989) Hátrány-e a határ mente? Figyeló, június 22. 7.

Erdősi F. (1988) A terület-és településfejlódés társadalmi-gazdasági folyamatai Magyarországon c. programhoz, MTA RKK Pécs.

Éger Gy. (1989) A burgenlandi magyarokról, Hitel, II. 23.

Fodor M. (1989) Gyarapítható-e a magyar falu? Hitel, II. 24.

Gadócziné Fekete É. (1987) Bódvaszilas és Hidvégardó mikroközösségének társadalmi, gazdasági fejlôdése 1900-1960-ig (Kézirat). 
Hornyik M. (1989) A tojástánc méltósága (a Bethlen Gábor-díjat kapott Szeli István laudációja), Hitel, II. 24.

Hoffmann M.-Lendvay I. (1986) A nemzetképek vizsgálatának elméleti és módszertani problémái. Ausztria és Magyarország esete (Belsố kiadvány) TKK Budapest.

Kapronczay J. (1987) Délnyugat-Baranya 42 határmenti településének természeti viszonyai, mezôgazdaságának jellemzése (Kézirat).

Kocsis K. (1987) A határmenti fekvés hatása egy régió népesedési viszonyaira (Kézirat).

Kovács T. (1988) Néhány módszertani elképzelés a határmenti térségek szociológiai vizsgálatához, In: A terület- és településfejlódés társadalmi-gazdasági folyamatai Magyarországon címú program, MTA RKK Pécs.

Lendvay I. (1983) Az osztrákok képe, (Belsổ kiadvány) Sopron, TKK, Budapest.

T. Mérey K. (1986) Iparforgalom a Drávaparti falvakban a kiegyezéstól a második világháború végéig (Kézirat). Majdán J. (1986) Horvát-magyar kapcsolatok 1867-1918 között (Kézirat).

Mit kíván a csehszlovákiai magyarság? Hitel, II. 1986. 23.

Sikó Á. (1987) Szociálgeográfiai megfigyelések Baranya déli határterületének településeiben (Kézirat).

Szabó M. (1986) Területfejlesztés Gyór-Sopron megye nyugati határvidékén, Gazdálkodás, XXX. 12.

Szóró I.-Olasz L. (1989) Öttömös és Pusztamérges (Kézirat).

Tiner T. (1987) Allamhatármenti térségek közlekedési viszonyai, (BAZ) megyei vizsgálat (Kézirat).

Tóth J. (1989) A határmentiség szerepe Szentpéterfa község gazdasági, társadalmi életében (Kézirat).

Tóth J.-Csatári B. (1983) Az Alföld határmenti területeinek vizsgálata, Terulleti Kutatások 6.

Tóth L. (1986) Közép-Európa nem volt, hanem lesz... Hitel, II. 23.

Végváriné B. I. (1987) Határmenti területek fejlesztési problémáinak feltárása. A trianoni békeszerzốdés hatása az ország mezógazdaságára (Kézirat).

Végváriné B. I. (1987) Határmenti területek fejlesztési problémáinak feltárása. A Békés-és Hajdú-Bihar megyei román határszakasz (Kézirat).

Vuics T. (1987) Az élelmiszer-gazdaság integráciojának jelentơsége Dél-Dunántúl határmenti településein (Kézirat). Wallerstein, I. (1983) A modern vilaggazdasági rendszer kialakulása, Gondolat, Budapest.

Zimányi V. (1978) Immanuel Wallerstein: Az új világrendszer, Valóság, 8.

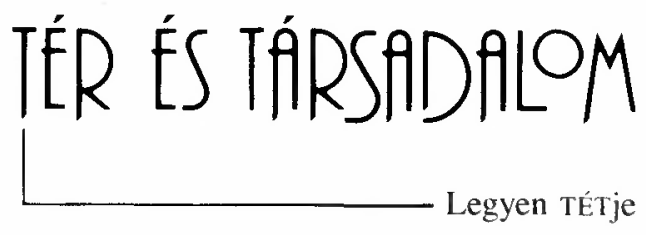




\section{THE ROLE OF FRONTIER LOCATION IN THE LIFE OF RURAL SETTLEMENTS}

\section{TERÉZ KOVÁCS}

In the Centre for Regional Studies of the Hungarian Academy of Sciences an overall research project started in 1986 on frontier location.

Until now, the issue of frontier location has almost exclusively been dealt with the geographers. The present study intends to approach this problem from sociological aspects, thus it fills a gap.

In contrast to geographers, who speak about frontier location as an (economic) periphery, the author emphasizes that these were not the regions located near the frontier which became peripheries, but the whole region became part of the empire region (according to Wallerstein's expression). The charasteristic of a "modern empire" (strong central management and control, negligence of national features) were charasteristic of Hungary's economic and social conditions between 1947 and 1989, and it hindered the development of settlements located near the frontier location itself. Frontier location might have secondary or tertiary, but definitely not primary role in the backwardness of rural areas. Population decrease, charasteristic of all the backwarded areas of the country, and can be related to those socio-economic tendencies and settlement policies, which existed in Hungary from the 1960s. The inhabitants of villages located near the frontier do not feal it either, that the reasons of the backwardness of their settlement should be found in frontier location. These people are realistic, and the lack of jobs and cities are everyday problems for them; more precisely they know that the latter are "far away" from them. The reasons of the unfavourable development of villages located near the frontier were the following: bad infrastructural supply and poor transportation facilities, unfavourable natural conditions, the lack of the tradition of individual entrepreneurship and their accumulation.

The study mentions, that between 1920 and 1937 , Hungary belonged to the periphery as Wallerstein means it, and at that time, the frontier was not strict, people could cross it practically freely. The most open was the Austro-Hungarian frontier. At that part, people crossed the the frontier not only in order to participate at the regular weekly markets, but the Hungarian went to Austria for daywork, because they were paid better. However, the Austrian bricklayers came over to Hungary to build houses, because they were acknowledged masters. The dayworkers of the villages located near the frontier met a more developed labour culture and used better tools, and they introduced them in Hungary as well. The Hungarian students of Burgenland came to study at the secondary school of Sopron and Kôszeg.

Earlier connections and relationship, however, could not be sustained between the regions inhabited by Hungarians on both sides of the frontier. The reason was, that the neighbouring countries feared reannexation much more at these parts, than at the parts where the artificial frontier was the same as the national one.

In the era called "modern empiricism" in the study, the conditions to establish relatives were 
not given. Whatever relations and connections did develop, they did it spontaneously, without the control, or often enough in spite of the intentions, of the central organizations.

The changes which started to take place in Eastern-Europe in 1989 let us conclude, that the frontiers will become less rigid, and we are right before the development of many-sided relationship. Hopefully, this will result in an ideal state when frontiers are only lines on the map.

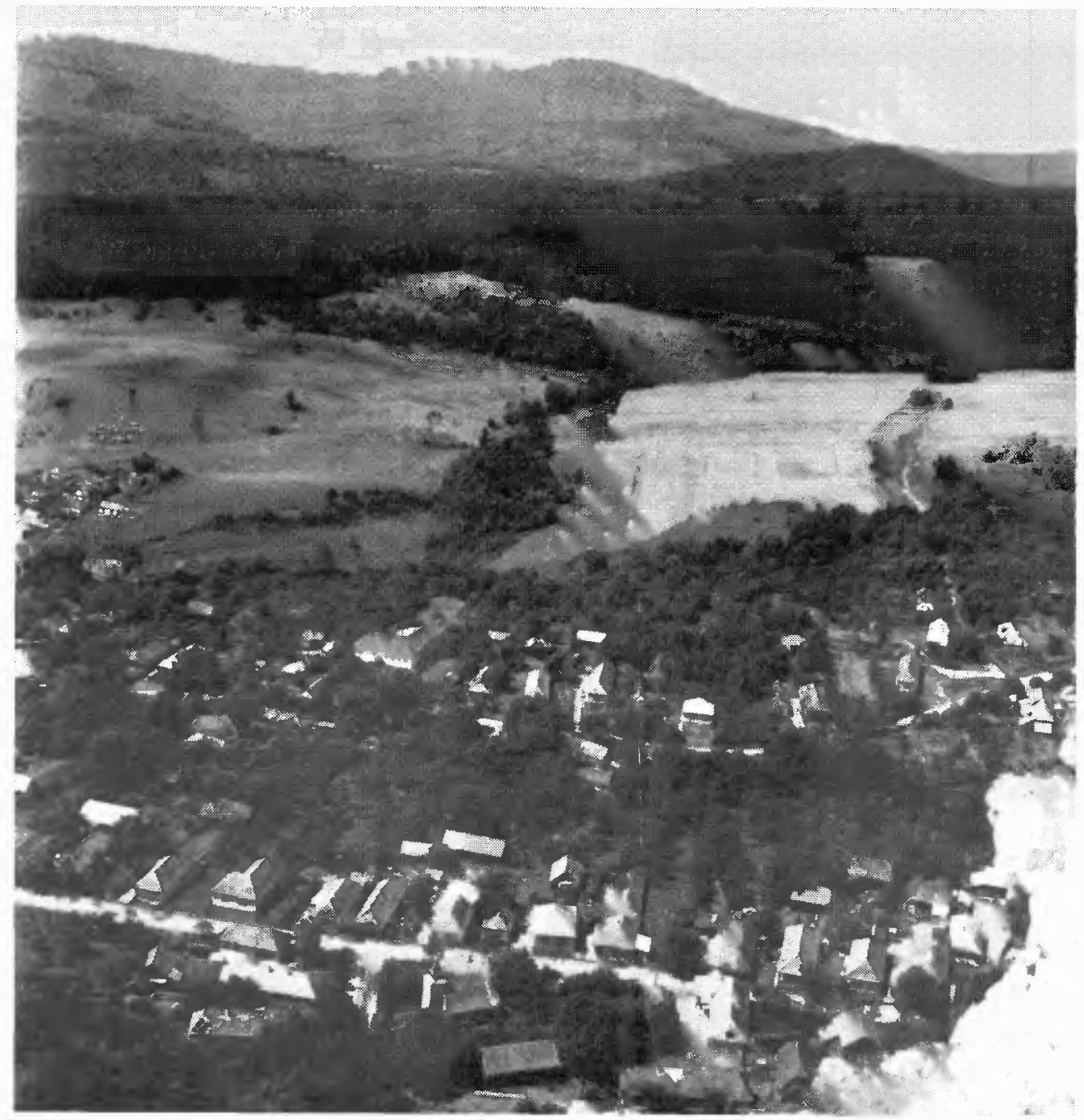

Még magasról nézvést megvolna... Füzér, a szlovák-magyar határon, a Zempléni hegység irtványában 
Kovács Teréz: A határmenti fekvés szerepe a falusi települések életében.

Tér és Társadalom, 5. 1991. 1. 41-54. p.

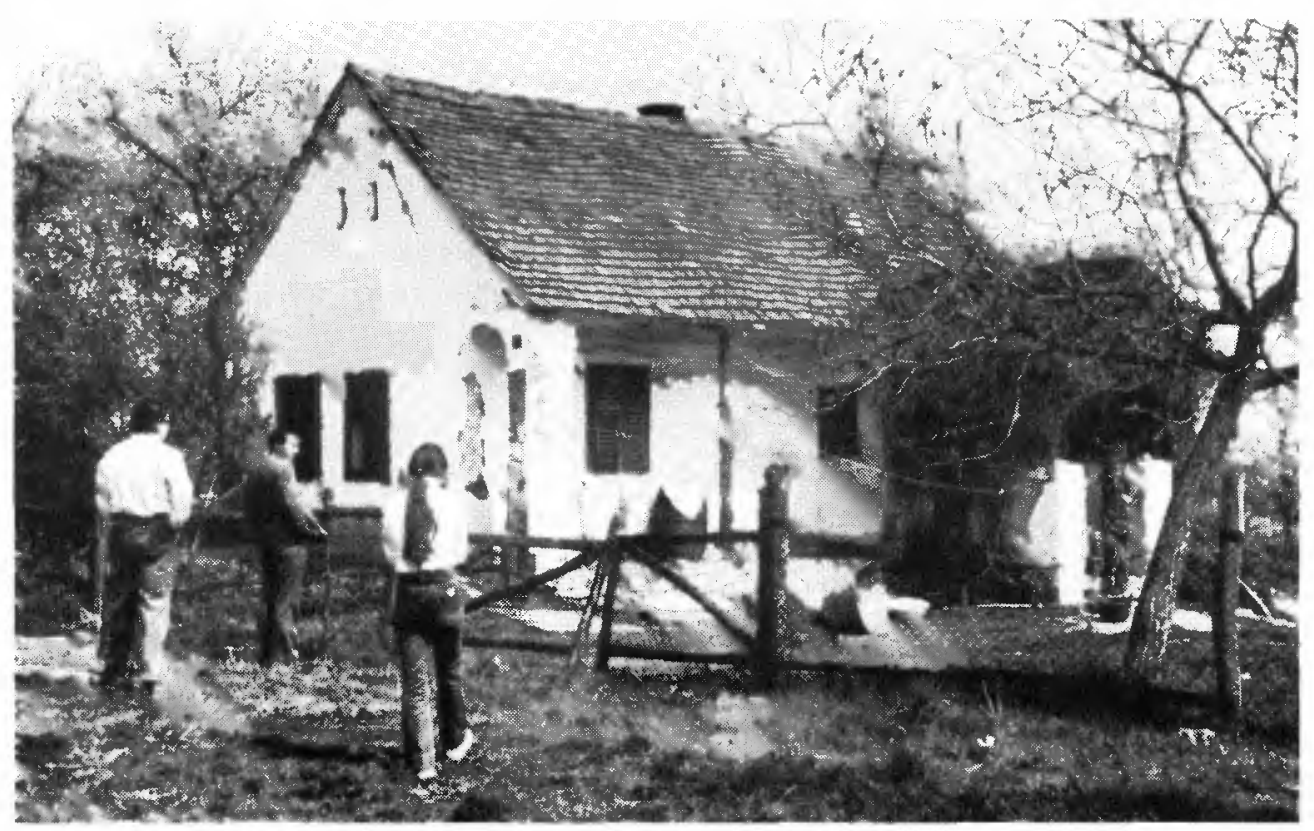

A határmente a falupusztulás jellegzetes terepe. A teljes pusztulás képe Korpádon. 